ISSN : $2302-1590$

E-ISSN: $2460-190 \mathrm{X}$

ECONOMICA

Journal of Economic and Economic Education Vol.4 No.1 (61-74)

\title{
PENINGKATAN AKTIVITAS BELAJAR MAHASISWA DALAM PEMBELAJARAN AKTIF TIPE BOWLING CAMPUS PADA MATA KULIAH PENILAIAN HASIL BELAJAR EKONOMI PADA SESI B TAHUN ANGKATAN 2014 PRODI PENDIDIKAN EKONOMI STKIP PGRI SUMATERA BARAT
}

\author{
Sri Wahyuni \\ Dosen Program Studi Pendidikan Ekonomi STKIP- PGRI Sumbar \\ Jl. Gunung Pangilun No.1, Padang Sumatera Barat \\ Email : sriwahyuni_ajeng@gmail.com
}

Submitted: 2016.06.22 Reviewed: 2016.06.22 Accepted: 2016.06.23

http://dx.doi.org/10.22202/economica.2015.v4.i1.639

\begin{abstract}
This study aims to look at the picture of the type Bowling Campus Active learning course on the economic assessment of learning outcomes of economic education courses STKIP PGRI West Sumatra. The type of research is a class act. In this study consisted of two cycles and each cycle consisting of two meetings. In cycle one and cycle two consists of seven indicators. Where the first cycle of each activity an increase of seven indicator that there is the ability to understand the material $37.5 \%$, the ability to observe, ability menjelaskan $50,0 \%, 42.5 \%$ the ability to give an example, the ability to ask and work together 32, 5\%, 45\% the ability to convey ideas, provide feedback 37.5\%, 35.0\% concluded capabilities. In the second cycle of each activity to achieve an increase of seven indicators that there is the ability to understand an increase of $87.5 \%$, the ability to explain an increase of $82.5 \%$, the ability to give an example of an increase of 87.5 , the ability to ask and work the same has increased by $90.0 \%$, the ability to convey ideas to increase by $90.0 \%$, giving the responses increased by $87.5 \%$, the alibity to conclude increased by $85.0 \%$.
\end{abstract}

Abstrak

Penelitian ini bertujuan untuk melihat gambaran tentang pembelajaran Aktif Tipe Bowling Campus pada mata kuliah penilaian hasil belajar ekonomi program studi pendidikan ekonomi STKIP PGRI Sumatera Barat. Jenis dari penelitian ini adalah penelitian tindakan kelas. Dalam penelitian ini terdiri dari dua siklus dan setiap siklus terdiri dari dua pertemuan. Pada siklus satu dan siklus dua terdiri tujuh indikator. Dimana pada siklus I masing-masing aktifitas terjadi peningkatan dari tujuh indicator yang ada yaitu kemampuan dalam mengerti tentang materi 37,5\%, kemampuan mengamati, kemampuan menjelaskan50,0\%, kemampuan memberikan contoh 42,5\%, kemampuan bertanya dan bekerja sama 32,5\%,kemampuan menyampaikan gagasan 45\%, memberikan tanggapan 37,5\%, kemampuan menyimpulkan 35,0\%. Pada siklus II masing-masing aktifitas yang ingin dicapai terjadi peningkatan dari tujuh indikator yang ada yaitu kemampuan mengerti mengalami peningkatan 87,5\%, kemampuan menjelaskan mengalami kenaikan 82,5\%, kemampuan memberikan contoh mengalami kenaikan sebesar 87,5, kemampuan bertanya dan bekerja sama mengalami kenaikan sebesar 90,0 \%, kemampuan menyampaikan gagasan mengalami kenaikan sebesar 90,0\%, memberikan tanggapan mengalami kenaikan sebesar 87,5\%, kemampuan menyimpulkan mengalami kenaikansebesar $85,0 \%$.

Keywords: bowling campus, STKIP PGRI of West Sumatra, outcome learning 


\section{PENDAHULUAN}

Pendidikan memegang peran penting dan merupakan kunci untuk semua kemajuan dan perkembangan yang berkualitas, sebab dengan pendidikan tersebut manusia dapat mewujudkan potensi dirinya sebagai pribadi maupun sebagai warga masyarakat. Untuk mewujudkan potensi diri menjadi individu yang memiliki banyak kompetensi harus melewati proses pendidikan yang diwujudkan dalam proses pembelajaran.

Pendidikan di kampus mempunyai tujuan untuk mengubah mahasiswa agar dapat memiliki pengetahuan, keterampilan dan sikap belajar sebagai bentuk perubahan dari hasil belajar. Keberhasilan proses dan hasil pembelajaran di kelas dipengaruhi oleh banyak faktor, baik secara intrinsik maupun secara ekstrinsik ataupun dapat ditimbulkan dari segi dosen dan mahasiswa itu sendiri.

Kegiatan belajar merupakan kegiatan yang paling pokok dalam keseluruhan proses pembelajaran (Slameto, 2003). Hasil belajar merupakan hal yang tidak dapat dipisahkan dengan proses belajar. Belajar merupakan serangkaian kegiatan yang dilakukan manusia sehingga terjadi perubahan tingkah laku pada dirinya. Seseorang yang belajar, mengharapkan hasil belajar berupa perubahan tingkah laku, pengetahuan, dan keterampilan yang bisa diterapkan dalam kehidupan. Keberhasilan proses pengajaran ditentukan oleh bagaimana proses itu berlangsung yakni proses interaksi antara guru dan siswa di dalam kelas. Keberhasilan belajar peserta didik dapat dilihat dari perubahan-perubahan yang dicapai meliputi pengetahuan, pemahaman, keterampilan, sikap, tingkah laku, dan lain-lain. Sehingga dosen dituntut untuk menciptakan suasana belajar yang lebih baik agar mahasiswa termotivasi dalam belajar. Pada saat kegiatan pembelajaran berlangsung, ketika terjadi interaksi antara dosen dan mahasiswa.

Didalam proses pembelajaran posisi dosen masih sangat dominan, sementara mahasiswa kebanyakan pasif dan menerima apa yang disampaikan oleh dosen. Kebanyakan dosen beranggapan kalau tidak menggunakan metode ceramah maka kita tidak mengajar. Pada hal dalam proses pembelajaran mahasiswa dituntut untuk aktif dan dosen didalam kelas sebagai fasilitator dan mediator dalam proses pembelajaran. Dari hasil observasi yang peneliti lakukan pada mata kuliah penilaian hasil belajar ekonomi untuk tiga kelas masih banyak mahasiswa yang fasif dalam proses pembelajaran dan mendengarkan saja apa yang diberikan dosen. Untuk lebih jelasnya dapat dilihat pada tabel dibawah ini:

Tabel 1: Aktivitas Belajar Mahasiswa pada mata kuliah PHB Tahun Angkatan 2014

\begin{tabular}{llll}
\hline Sesi & Jumlah Mahasiswa & $\begin{array}{l}\text { Mahasiswa Yang Aktif Pada } \\
\text { Proses Pembelajaran }\end{array}$ & Persentase \\
\hline Sesi A 2014 & 38 Orang & 15 Orang & 39,4 \\
Sesi B 2014 & 40 Orang & 7 Orang & 17,5 \\
Sesi C 2014 & 38 Orang & 14 Orang & 36,8 \\
\hline
\end{tabular}

Sumber: Dosen Pengampu Mata kuliah

Berdasarkan data diatas terdapat tiga kelas atau tiga sesi pada pembelajaran penilaian hasil belajar Ekonomi yang terdiri dari tiga delapan sampai empat puluh orang maahsiswa per sesi. Dari tiga sesi tersebut sesi B 2014 yang mempunyai keaktifan yang lebih rendah dibandingkan dengan sesi A dan C. Dimana pada setiap proses pembelajaran mahasiswa hanya banyak diam dan mendengarkan apa yang 
disampaikan oleh dosen tanpa ada komentar atau pertanyaan.

Untuk mengaktifkan belajar mahasiswa dalam proses belajar mengajar, dosen harus menggunakan metode yang bervariasi, oleh sebab itu sangat dianjurkan agar dosen menggunakan kombinasi metode mengajar setiap kali mengadakan kegiatan pembelajaran (Sudjana, 2002: 76).

Penyampaian materi pelajaran yang kurang bervariasi dan cenderung menggunakan metode ceramah membuat sebagian mahasiswa bosan. Karena metode pembelajaran yang digunakan dosen adalah metoda ceramah sehingga kurang terciptanya interaksi antara mahasiswa dengan dosen, karena dosen terlalu banyak mendominasi proses belajar. Sedangkan mahasiswa hanya mendengarkan penjelasan yang diberikan oleh dosen. Komunikasi juga berlangsung satu arah yaitu dosen mentransfer pengetahuan kepada mahasiswa, sedangkan mahasiswa hanya mendengarkan, mencatat dan mengerjakan latihan secara mandiri selama proses pembelajaran. Pembelajaran yang berpusat pada dosen ini membuat mahasiswa menjadi pasif dan kurang berpartisipasi dalam pembelajaran, sehingga aktiviatas belajar mahasiswapun menjadi kurang maksimal.

Salah satu upaya yang dapat
dilakukan dosen untuk membantu mahasiswa supaya aktif dan lebih memahami materi yang disampaikan adalah dengan menggunakan pembelajaran yang tepat sehingga tujuan pembelajaran dapat tercapai. Menurut Hamzah (2008: 2) strategi pembelajaran merupakan cara-cara yang akan dipilih dan digunakan oleh seorang pengajar untuk menyampaikan materi pembelajaran sehingga akan memudahkan peserta didik menerima dan memahami materi pembelajaran, yang pada akhirnya tujuan pembelajaran dapat dikuasainya diakhir kegiatan belajar.
Menurut Silberman (2013: 261) tentang pembelajaran aktif tipe bowling campus adalah alternatif dalam peninjauan ulang kembali. Salah satu cara yang pasti untuk membuat pembelajaran tetap melekat dalam pikiran adalah dengan mengalokasikan waktu untuk meninjau kembali apa yang telah dipelajari. Materi yang telah dibahas oleh mahasiswa cenderung lima kali lebih melekat di dalam pikiran dibandingkan materi yang tidak dibahas oleh dosen, karena pembahasan kembali memungkinkan mahasiswa untuk memikirkan kembali informasi tersebut dan menemukan cara untuk menyimpannya di dalam otak.

Pembelajaran aktif tipe bowling campus memiliki kelebihan seperti dosen akan mengetahui sejauh mana mahasiswa sudah mengerti tentang pelajaran yang diterangkan, anak akan mendapakan kesempatan untuk menjawab pertanyaan, dan mahasiswa akan berlomba-lomba menjawab pertanyaan yang diberikan dosen, karena diakhir pembelajaran akan diumumkan kelompok siapa yang mendapat skor tertinggi atau pemenang. Diharapkan dalam penerapan atau penggunaan pembelajaran aktif tipe bowling campus ini, nantinya dapat lebih meningkatkan hasil belajar mahasiswa Berdasarkan permasalaha diatas maka peneliti tertarik melakukan penelitian mengenai "Peningkatan Aktivitas Belajar Mahasiswa Melalui Pembelajaran Aktif Tipe Bowling Campus pada mata kuliah Penilaian Hasil Belajar Ekonomi Pada Sesi B Tahun Angkatan 2014 Pada Prodi Pendidikan Ekonomi STKIP PGRI Sumatera Barat.

\section{LANDASAN TEORI}

\section{A. Hasil Belajar}

Hasil belajar merupakan hal yang tidak dapat dipisahkan dengan proses belajar. Belajar merupakan serangkaian kegiatan yang dilakukan manusia sehingga terjadi perubahan tingkah laku pada dirinya. 
Seseorang yang belajar, mengharapkan hasil belajar berupa perubahan tingkah laku, pengetahuan, dan keterampilan yang bisa diterapkan dalam kehidupan. Bagi siswa, hasil belajar adalah gambaran untuk mengetahui apakah dirinya berhasil atau gagal dalam mempelajari suatu materi pembelajaran.

Hasil belajar merupakan tolak ukur yang digunakan untuk menentukan tingkat keberhasilan siswa dalam memahami konsep dalam belajar. Menurut pendapat Mulyasa (2010: 212) hasil belajar merupakan prestasi belajar peserta didik secara keseluruhan yang menjadi indikator kompetensi dasar dan derajat perubahan prilaku yang bersangkutan. Hal ini sejalan dengan pendapat Hamalik (2011: 27) mengatakan bahwa hasil belajar bukan suatu penguasaan hasil latihan, melainkan pengubahan kelakuan. Pengertian ini menitik beratkan pada interaksi antara individu dengan lingkungan.

Menurut Dimyati dan Mudjiono (2009: 250-251), hasil belajar merupakan hal yang dapat dipandang dari dua sisi yaitu dari sisi siswa dan dari sisi guru. Dari sisi siswa, hasil belajar merupakan tingkat perkembangan mental yang lebih baik bila dibandingkan pada saat sebelum belajar. Tingkat perkembangan mental tersebut terwujud pada jenis-jenis ranah kognitif, afektif, dan psikomotor. Sedangkan dari sisi guru, hasil belajar merupakan saat terselesaikannya bahan pelajaran. Menurut Hamalik (2009: 155) "Hasil belajar tampak sehingga terjadinya perubahan tingkah laku pada diri siswa yang dapat diamati dan diukur dalam bentuk perubahan pengetahuan sikap dan keterampilan. Perubahan tersebut dapat diartikan terjadinya peningkatan dan pengembangan yang lebih baik dibandingkan dengan sebelumnya, misal dari tidak tahu menjadi tahu".
Sedangkan menurut Gagne dalam Dahar (2006: 118-124) membagi lima kategori hasil belajar, yakni:

1. Keterampilan intelektual, adalah kemungkinan seseorang berinteraksi dengan lingkungannya melalui pengguaan simbol-simbol atau gagasan-gagasan.

2. Strategi kognitif, suatu macam keterampilan intelektual khusus yang mempunyai kepentingan tertentu bagi belajar dan berpikir.

3. Informasi verbal, diperoleh sebagai hasil belajar di sekolah dan juga dari kata-kata yang diucapkan orang, membaca dari radio, televisi dan media lainnya.

4. Sikap, Sikap merupakan pembawaan yang dapat dipelajari, dan dapat mempengaruhi perilaku seseorang terhadap benda, kejadian-kejadian, atau mahkluk-mahkluk hidup lainnya.

5. Keterampilan motorik tidak hanya mencakup kegiatan-kegiatan fisik, melainkan juga kegiatan-kegiatan motorik yang digabung dengan keterampilan intelektual.

Sedangkan faktor-faktor yang mempengaruhi hasil belajar menurut Slameto (2003: 46) adalah sebagai berikut :

a. Faktor Internal

1) Faktor biologis (jasmaniah)

Keadaan jasmani yang perlu diperhatikan, pertama kondisi fisik yang normal atau tidak memiliki cacat sejak dalam kandungan sampai sesudah lahir. Kondisi fisik normal ini terutama harus meliputi keadaan otak, panca indera, anggota tubuh. Kedua, kondisi kesehatan fisik. Kondisi fisik yang sehat dan segar sangat mempengaruhi keberhasilan belajar. Di dalam menjaga kesehatan fisik, ada beberapa hal yang perlu diperhatikan antara lain makan dan 
minum yang teratur, olahraga serta cukup tidur.

\section{2) Faktor Psikologis}

Faktor psikologis yang mempengaruhi keberhasilan belajar ini meliputi segala hal yang berkaitan dengan kondisi mental seseorang. Kondisi mental yang dapat menunjang keberhasilan belajar adalah kondisi mental yang mantap dan stabil. Faktor psikologis ini meliputi halhal berikut. Pertama, intelegensi. Intelegensi atau tingkat kecerdasan dasar seseorang memang berpengaruh besar terhadap keberhasilan belajar seseorang. Kedua, kemauan. Kemauan dapat dikatakan faktor utama penentu keberhasilan belajar seseorang. Ketiga, bakat. Bakat ini bukan menentukan mampu atau tidaknya seseorang dalam suatu bidang, melainkan lebih banyak menentukan tinggi rendahnya kemampuan seseorang dalam suatu bidang.

b. Faktor eksternal

1) Faktor lingkungan keluarga

Faktor lingkungan rumah atau keluarga ini merupakan lingkungan pertama dan utama pula dalam menentukan keberhasilan belajar seseorang. Suasana lingkungan rumah yang cukup tenang, adanya perhatian orang tua terhadap perkembangan proses belajar dan pendidikan anak-anaknya maka akan mempengaruhi keberhasilan belajarnya.

2) Faktor lingkungan sekolah Lingkungan sekolah sangat diperlukan untuk menentukan keberhasilan belajar siswa. Hal yang paling mempengaruhi keberhasilan belajar para siswa di sekolah mencakup metode mengajar, kurikulum, relasi guru dengan siswa, relasi siswa dengan siswa, pelajaran, waktu sekolah, tata tertib atau disiplin yang ditegakkan secara konsekuen dan konsisten.

3) Faktor lingkungan masyarakat
Seorang siswa hendaknya dapat memilih lingkungan masyarakat yang dapat menunjang keberhasilan belajar. Masyarakat merupakan faktor ekstern yang juga berpengruh terhadap belajar siswa karena keberadannya dalam masyarakat. Lingkungan yang dapat menunjang keberhasilan belajar diantaranya adalah, lembaga-lembaga pendidikan non formal, seperti kursus bahasa asing, bimbingan tes, pengajian remaja dan lain-lain.

Dapat disimpulkan bahwa hasil belajar dapat dipandang dari siswa, apakah siswa telah memperoleh pengetahuan dengan belajar. Dari sisi guru bagaimana guru tersebut menciptakan pembelajaran yang dapat membangkitkan kegairahan peserta didik dalam belajar, dan juga menggunakan metode pembelajaran yang sesuai dengan peserta didik.

\section{Proses Pembelajaran}

Pembelajaran merupakan kegiatan yang sangat penting dalam menentukan tujuan dari suatu pendidikan. Pembelajaran adalah suatu proses perubahan yang terjadi karena reaksi dari situasi yang dihadapi oleh seseorang. Dapat diartikan bahwa, proses pembelajaran itu terjadi karena pengalaman yang pernah dihadapi. Perubahan ini dimaksudkan untuk dapat membuat seseorang belajar.

Proses pembelajaran merupakan kegiatan yang sangat penting dalam menentukan pencapaian tujuan dari suatu pendidikan di sekolah. Belajar adalah suatu proses perubahan tingkah laku individu yang terjadi akibat interaksi dengan lingkungannya. Belajar merupakan suatu proses untuk mencapai tujuan dengan melakukan langkah-langkah atau prosedur yang ditempuh. Belajar merupakan kegiatan penting bagi setiap orang, termasuk di dalamnya belajar bagaimana seharusnya belajar. 
Pada dasarnya proses belajar ditandai dengan perubahan tingkah laku secara keseluruhan baik yang menyangkut segi kognitif, afektif maupun psikomotor. Proses perubahan dapat terjadi dari yang paling sederhana sampai yang paling kompleks, yang bersifat pemecahan masalah dan pentingnya peranan dalam proses serta hasil belajar. (Tim pengembang MKDP, 2011: 140)

Belajar adalah suatu proses untuk memperoleh suatu perubahan tingkah laku yang baru secara keseluruhan, sebagai hasil pengalaman seseorang dalam interaksi dengan lingkungannya (Slameto, 2003: 2). Proses belajar merupakan kegiatan yang penting yang dilakukan setiap orang secara maksimal untuk menguasai dan memperoleh sesuatu. Menurut Aunurrahman (2009: 35) dalam proses pembelajaran, hasil belajar dapat dilihat secara langsung. Oleh sebab itu agar dapat dikontrol dan berkembang secara optimal melalui proses pembelajaran di kelas, maka program pembelajaran tersebut harus dirancang terlebih dahulu oleh guru dengan memperhatikan berbagai prinsip yng telah terbukti keunggulannya secara empirik

Sabri (2007: 19) yang menyatakan bahwa "Belajar adalah proses perubahan perilaku berkat pengalaman dan pelatihan". Artinya tujuan kegiatan belajar ialah perubahan tingkah laku, baik yang menyangkut pengetahuan, keterampilan, sikap, bahkan meliput segenap aspek pribadi. Piaget (tanpa tahun) dalam Dimyati (2002: 38) memandang belajar sebagai perilaku berinteraksi antara individu dengan lingkungan sehingga terjadi perkembangan intelektual individu.

Proses pembelajaran akan berlangsung lancar dan baik jika masingmasing komponen menyadari tugas dan tanggung jawabnya. Guru dan siswa harus tahu apa yang menjadi tugas mereka masing-masing. Antara guru dan siswa juga terdapat hubungan atau komunikasi yang saling mempengaruhi. Belajar yang terjadi pada individu merupakan perilaku kompleks, tindak interaksi antara guru dan siswa yang bertujuan (Dimyati, 2002: 39). Begitu juga dengan siswa yang memiliki tanggung jawab untuk menguasai dan memperoleh pengetahuan baru untuk kemajuan dan perubahan tingkah lakunya menuju arah yang lebih baik. Selain melaksanakan tugasnya sebagai fasilitator pembelajaran, seorang guru harus mengacu pada tujuan akhir proses pembelajaran itu. Di sekolah, guru hendaknya dapat menggunakan strategi, pendekatan, metode, dan teknik pembelajaran aktif yang banyak melibatkan siswa, sehingga siswa dapat aktif untuk belajar.

\section{B. Aktifitas Belajar}

Aktivitas belajar adalah aktivitas yang bersifat fisik maupun mental, dan kedua aktivitas belajar itu harus selalu berkait. Menurut Paiget (2001:98) : seorang anak itu berfikir sepanjang ia berbuat. Tanpa berbuat berati anak itu tidak berpikir. Untuk itu agar anak berpikir sendiri maka harus diberi kesempatan untuk berbuat sendiri. Berpikir pada taraf verbal baru akan timbul setelah anak itu berpikir pada taraf perbuatan.

Adapun jenis-jenis aktivitas dalam belajar menurut Paul B. Diedrich dalam sardiman (2001: 99) dapat diklasifikasikan sebagai berikut:

a. Visual activities, yang termasuk didalamnya membaca, memperhatikan gambardemonstrasi, percobaan pekerjaan orang lain.

b. Oral activities, seperti: menyatakan, merumuskan, bertanya, member saran, mengeluarkan pendapat, mengadakan wawancara, diskusi, interupsi

c. Writing Activities, seperti: menulis, cerita, karangan, laporan, menyalin, angket 
d. Listening Activities, seperti: mendengarkan, uraian, percakapan, diskusi, music dan pidato

e. Drawing activities, seperti: menggambar, membuat grafik, peta dan diagram

f. Motor Actvities, Seperti: melakukan percobaan, membuat konstruksi, model, mereparasi, bermain, berkebun, dan beternak.

g. Mental Activities, Seperti: mengingat, memecahkan soal, menganalisis, melihat hubungan, mengambil keputusan.

h. Emosional Activities, Seperti: menaruh minat, merasa bosan, gembira, bersemangat, bergairah, barani, tenang, gugup.

Aktivitas disekolah cukup kompleks dan bervariasi. Jika kegiatan atau aktiviatas tersebut dapat dilaksanakan di sekolah dengan baik, proses aktivitas tersebut dapat dilaksanakan disekolah dengan baik. Aktivitas belajar siswa yang maksimal akan mempelancar tujuan pembelajaran yang hendak dicapai.

\section{Belajar aktif}

Seorang siswa dapat dikatakan telah belajar aktif apabila siswa tersebut dalam proses pembelajaran sudah melakukan sebagian besar pekerjaannya, mampu dan berani mengemukakan pendapat dan mengajukan pertanyaan, membuat kesimpulan, menerapkan apa yang dipelajari, mendiskusikan serta mengajukannya pada orang lain.

Belajar merupakan proses perubahan dari hasil interaksi dengan lingkungan untuk memenuhi kebutuhan fisik, mental dan spiritual. Perubahan tersebut mencakup, aspek tingkah laku, keterampilan dan pengetahuan. Seseorang akan aktif belajar apabila dia memiliki motivasi, dan siswa aktif akan biasa melakukan sebagian besar pekerjaannya, dan belajar merupakan suatu proses dalam memperoleh pengalaman dan pengetahuan baru yang menghasilkan perubahan tingkah laku yang bersifat tetap.

Seseorang yang telah belajar akan mengalami perubahan tingkah laku dan pengetahuan kea rah yang lebih baik dibandingkan sebelum dia mengalami proses belajar.

\section{Pembelajararan Cooperative (cooperative Learning)}

Pembelajaran Cooperative merupakan model pembelajaran dengan kelompok. Siswa dalam pembelajaran ini diharapkan dapat bekerja sama dan saling membantu dengan anggota kelompoknya untuk mempelajari materi pelajaran dan tugastugas yang diberikan guru.

Menurut Mulim Ibrahim (2003:3): model pembelajaran komperatif adalah menuntut kerja sama siswa dan saling ketergantungan dalam struktur, tujuan dan hadiah". Jadi dengan kerja kelompok dapat mengaktifkan siswa, sebab dalam kelompok mereka akan bekerja sama, dan berdiskusi untuk mengerjakan tugas.

Pembelajaran kooperatif mempunyai beberapa manfaat, menurut Anita Lie dalam Anam (2002:2) adalah: (1) siswa dapat meningkatkan kemampuannya untuk bekerja sama dengan siswa lain (2) Siswa mempunyai lebih banyak kesempatan untuk menghargai perbedaan (3) Partisipasi siwa dalam proses belajar meningkat (4) Mengurangi kecemasan siswa( kurang percaya diri (5) meningkatkan motivasi, harga diri dan sikap positif (6) Meningkatkan prestasi siswa

Peranan guru dalam pembelajaran kooperatife sangat kompleks. Guru sebagai fasilitator juga sebagai manajer dan konsultan dalam memberdayakan kerja kelompok siswa, guru harus bisa memotivasi siswa untuk aktif dan berpartisipasi dalam kegiatan belajar. Pada pembelajaran cooperative dikenal enam fase yang harus dilalui oleh guru dan siswa yang terlibat 
dalam proses dan pembelajaran. Fase tersebut ditujukan pada table dibawah ini.

\section{E. Pembelajaran Aktif Tipe Bowling Campus}

Pembelajaran aktif adalah segala bentuk pembelajaran yang memungkinkan siswa berperan secara aktif dalam proses pembelajaran itu sendiri baik dalam bentuk interaksi antar siswa maupun siswa dengan guru dalam proses pembelajaran tersebut. Selama ini proses pembelajaran lebih sering diartikan sebagai guru menjelaskan materi pelajaran dan siswa mendengarkan secara pasif. Namun pembelajaran pada dasarnya adalah proses penambahan informasi dan kemampuan baru. Ketika kita berpikir, informasi dan kemampuan apa yang harus dimiliki oleh siswa, maka pada saat itu juga kita semestinya berpikir strategi apa yang harus dilakukan agar semua itu dapat tercapai secara efektif dan efesien.

Pembelajaran tidak hanya menekankan pada apa yang diajarkan tetapi juga bagaimana mengajarkannya. Salah satunya dengan menerapkan strategi pembelajaran dalam proses belajar mengajar. Kemp (1995) dalam Sanjaya (2006: 126) menjelaskan bahwa strategi pembelajaran adalah suatu kegiatan pembelajaran yang harus dikerjakan guru dan siswa agar tujuan pembelajaran dapat dicapai secara efektif dan efesien.

Meyer dan Jones (1993) dalam Ramdhani (2013) mengemukakan bahwa pembelajaran aktif juga terjadi aktivitas berbicara dan mendengar, menulis, membaca, dan refleksi yang menggiring ke arah pemaknaan mengenai isi pelajaran, ideide, dan berbagai hal yang berkaitan dengan satu topik yang sedang dipelajari. Pada pembelajaran aktif, guru lebih berperan sebagai fasilitator bukan pemberi ilmu. Hal yang sangat penting dalam upaya penerapan pembelajaran aktif di dalam kelas salah satunya adalah guru mengontrol berbagai aktivitas sehingga tidak hanya mengenai apa yang dipelajari siswa tetapi lebih ke bagaimana mereka mempelajari topik tersebut (Ramdhani, 2013).

Menurut Bonwell dalam Supinah (2013: 3), pembelajaran aktif memiliki karakteristik-karakteristik sebagai berikut:

1. Penekanan proses pembelajaran bukan pada penyampaian informasi oleh pengajar melainkan pada pengembangan keterampilan pemikiran analitis dan kritis terhadap topik atau permasalahan yang dibahas.

2. Siswa tidak hanya mendengarkan secara pasif tetapi mengerjakan sesuatu yang berkaitan dengan materi pelajaran.

3. Penekanan pada eksplorasi nilai-nilai dan sikap-sikap berkenaan dengan materi pelajaran.

4. Siswa lebih banyak dituntut untuk berpikir kritis, menganalisa dan melakukan evaluasi.

5. Umpan-balik yang lebih cepat akan terjadi pada proses pembelajaran.

Salah satu contoh pembelajaran aktif adalah pembelajaran aktif tipe bowling campus (Silberman, 2013). Pembelajaran aktif tipe bowling campus merupakan alternatif dalam peninjauan ulang materi. Pembelajaran tipe ini memungkinkan guru mengevaluasi penguasaan materi pelajaran siswa, dan bertugas menguatkan, menjelaskan, dan mengikhtisarkan poin-poin utama materi pelajaran. Menurut Silberman (2013: 261-262) langkah-langkah atau prosedur dalam pembelajaran aktif tipe bowling campus adalah sebagai berikut: 1. Bagilah siswa menjadi beberapa tim beranggotakan tiga atau empat orang. Perintahkan tiap tim memilih nama organisasi (tim olah raga, perusahaan, kendaraan bermotor, dll) yang mereka wakili.

2. Beri tiap siswa kartu indeks. Siswa akan mengacungkan kartu mereka untuk menunjukan bahwa mereka ingin 
mendapatkan kesempatan menjawab pertanyaan. Format permainannya sama seperti lempar koin: tiap kali anda mengajukan pertanyaan, anggota tim boleh menunjuk keinginannya untuk menjawab.

3. Jelaskan aturan berikut ini:

a. Untuk menjawab sebuah pertanyaan, acungkan kartu kalian.

b. Kalian dapat mengacungkan kartu sebelum sebuah pertanyaan selesai diajukan jika kalian merasa sudah tahu jawabannya. Segera setelah kalian melakukan interupsi pembacaan pertanyaan itu dihentikan.

c. Tim menilai satu angka untuk tiap jawaban anggota yang benar

d. Ketika seorang siswa memberikan jawaban yang salah, tim lain bisa mengambil alih untuk menjawab (mereka dapat mendengarkan seluruh pertanyaan jika tim lain menginterupsi pembacaan pertanyaan)

4. Setelah semua pertanyaan diajukan, jumlahkan skornya dan umumkan pemenangnya.

5. Berdasarkan jawaban permainan, tinjaulah materi yang belum jelas atau yang memerlukan penjelasan lebih lanjut.

Pada penelitian ini, pembelajaran aktif tipe bowling campus dilaksanakan setelah siswa mengumpulkan laporan kelompoknya atau setelah proses belajar mengajar dari guru, barulah pembelajaran aktif ini diterapkan. Karena berdasarkan penjelasan mengenai pembelajaran aktif tipe bowling campus itu sendiri yaitunya peninjauan ulang materi artinya diakhir pelajaran guru mengajak siswa untuk mereview kembali materi yang telah diajarkan oleh guru melalui pertanyaanpertanyaan yang berkaitan dengan materi yang sedang dipelajari sesuai dengan prosedur pelaksanaan pembelajaran aktif tipe bowling campus. Tipe pembelajaran aktif ini dapat memberi pengaruh yang baik bagi siswa dalam mengukur kemampuan sendiri atau kelompok, kekurangan, kekeliruannya terhadap konsep yang mereka pelajari dan selanjutnya berusaha memperbaiki hasil belajarnya dengan bantuan dan bimbingan dari guru.

Untuk dapat mengukur aktifitas siswa dalam pembelajaran, perlu kiranya bagi kita mengetahui terlebih dahulu komponen-komponen aktivitas dan menentukan indikatornya terlebih dahulu, yang dimaksudkan aktifitas belajar adalah respon atau keterlibatan siswa baik secara fisik, mental, emosional maupun intelektual dalam setiap proses pembelajaran, meliputi: (1) aktifitas siswa dalam mempersiapkan diri sebelum mengikuti proses belajar dan pembelajaran, (2) aktifitas siswa selama mengikuti proses pembelajaran di kelas, dan (3) aktifitas siswa dalam evaluasi dan pemantapan pembelajaran yang dilakukan setelah mengikuti proses pembelajaran di kelas. Dengan demikian yang dimaksud dengan aktifitas belajar, adalah keterlibatan siswa dalam bentuk sikap, pikiran, perhatian dan aktifitas dalam kegiatan pembelajaran guna menunjang keberhasilan proses belajar mengajar dan memperoleh manfaat dari kegiatan tersebut. (Supinah, 2013: 8)

Adapun prosedur atau langkahlangkah yang dilakukan oleh penulis dalam menerapkan pembelajaran aktif tipe bowling campus tersebut adalah: 1) Menyampaikan tujuan pelajaran yang ingin dicapai pada pembelajaran tersebut dan memotivasi siswa untuk belajar, 2). Siswa dibagi kedalam beberapa kelompok, dimana setiap kelompoknya terdiri dari 4-5 siswa secara heterogen, 3). Guru membagikan kartu indeks untuk setiap siswa dengan nama kelompok yang berbeda, 4). Guru menyampaikan materi pelajaran dengan terlebih dahulu menjelaskan tujuan pelajaran yang ingin dicapai pada pertemuan tersebut serta pentingnya pokok bahasan tersebut dipelajari, 5). Guru membagikan bahan ajar kepada tiap kelompok siswa, 6). Siswa 
belajar atau diskusi dalam kelompok yang telah dibentuk sesuai dengan materi yang telah dibagikan guru, 7). Masing-masing kelompok siswa mempersentasekan hasil diskusinya didepan kelas dan bagi kelompok yang tidak mengerti boleh bertanya pada kelompok yang tampil, 8). Setelah penampilan semua kelompok selesai guru memberikan kuis sesuai dengan materi yang telah dijelaskan dan dibagikan, 9). Bagi kelompok yang dapat menjawab pertanyaan guru segera acungkan kartu indeks yang telah dibagikan, dan bagi kelompok yang tercepat mengacungkan kartu indeksnya dialah yang berkesempatan untuk menjawab pertanyaan yang diberikan guru, 10). Ketika kelompok yang bersangkutan salah dalam menjawab, maka kesemptan bagi kelompok lain untuk mengambil alih jawaban yang diberikan guru dengan cara mengacungkan kartu indeks kelompok mereka, 11). Guru akan memberikan reward bagi kelompok yang memperoleh skor tertinggi dalam memnjawab pertanyaan guru, dan 12) Terakhir guru memberikan penguatan dan kesimpulan mengenai materi yang telah dijelaskan dan didiskusikan oleh siswa.

\section{F. Hipotesis}

Berdasarkan rumusan masalah maka hipotesis dalam penelitian ini adalah “ Model Pembelajaran Aktif Tipe Bowling Campus pada mata kuliah Penilaian Hasil Belajar Ekonomi Pada Sesi B Tahun Angkatan 2014 Pada Prodi Pendidikan Ekonomi STKIP PGRI Sumatera Barat." Dapat meningkatkan aktivitas belajar mahasiswa

\section{METODOLOGI PENELITIAN}

Jenis penelitian ini adalah penelitian tindakan kelas (Classroom Action Research), dimana dalam kelas diberi tindakan (action). Dalam penelitian ini dilakukan observasi didalam kelas terhadap aktivitas siswa selama berlangsung proses belajar mengajar. Penelitian yang dilakukan adalah model spiral, satu putaran spiral satu siklus terdiri dari langkah-langkah perencanaan (plan), tindakan (action), pemantauan (observation) dan refleksi. Pada penelitian ini terdiri dari dua siklus. Satu Siklus terdiri dari dua pertemuan.

\section{Prosedur Penelitian}

\section{Refleksi Awal}

Dalam Refleksi awal ini kita melihat apa saja permasalah yang hihadapi dalam pembelajaran sebelumnya, yaitu siswa fasif dalam pembelajaran.

2. Siklus I

a. Perencanaan

Sebelum penelitian dilakukan, maka disusunlah perencanaan berbagai hal: 1) Mempersiapkan satuan acara pembelajaran, 2) Menyediakan lembaran kerja mahasiswa, analisis materi ajar, 3) Membut lembaran observasi

b. Tindakan (Action)

1) Guru menjelaskan Aktif Tipe Bowling Campus, 2) mahasiswa dibagi dalam beberapa kelompok kecil yang terdiri dari empat sampai 5 orang, 3) Dosen memberikan ringkasan materi, 4) Dosen mengacak beberapa kelompok untuk membacakan hasil diskusi, 5) Mahasiswa diberi tes atau kuis, 4) Nilai individu siswa dikumpilkan menjadi nilai kelompok, 5) Nilai Kelompok yang tinggi diberi pengakuan

c. Pemantauan (observasi)

Mencatat aktivitas siswa selama berlangsung proses belajar mengajar. Data pada table disusun berdasarkan data pada lembaran pengamatan.

d. Refleksi

Data yang diperoleh diolah secara kuantitatif (persentase) dan secara Kualitatif (deskripsi dengan kata-kat)

3. Siklus II

a. Perencanaan

Untuk siklus II masih dirasakan beberapa perbaikan dengan tindak merubah langkah- 
langkah umum yang dilakukan pada siklus pertama.

b. Tindakan

Untuk tindakan siklus kedua yang akan dilakukan adalah: 1) Setiap kelompok diberi tugas baca materi yang akan didiskusikan 2) Kemudian diambil nomor secara acak untuk mempersentasikan hasil diskusi kelompoknya, 3) Diberi setiap kesempatan tiap kelompok untuk bertanya atau tanggapan, 4) Membuat kesimpulan, 5) Mengadakan kuis dan tes, 6) Hasil kuis dikumpulkan setiap kelompok, nilai kelompok tertinggi diberi penguatan (hadiah) didepan kelas.

c. Pemantauan
Hal yang diamati siklus kedua sama dengan yang dilakukan siklus pertama d. Refleksi

Hasil yang dicapai dibandingkan dengan siklus pertama, apakah ada kemajuan atau tidak, sehingga pada siklus kedua ini akan diperoleh gambaran apakah penelitian sesuai dengan tujuan yang dirumuskan atau tidak.

\section{PEMBAHASAN}

Adapun hasil dari penelitian yang terdiri dari dua siklus yaitu siklus pertama dan siklus kedua.

\section{A. Hasil Penelitian}

Tabel 2. Tingkat Perubahan Aktivitas Mahasiswa Pada Siklus 1

\begin{tabular}{|c|c|c|c|c|c|c|}
\hline \multirow[t]{2}{*}{ No } & \multirow[t]{2}{*}{ Aktivitas Belajar PHB } & \multicolumn{2}{|c|}{ Pertemuan 1} & \multicolumn{2}{|c|}{ Pertemuan 2} & \multirow{2}{*}{$\begin{array}{c}\text { Tingkat Perubahan } \\
\%\end{array}$} \\
\hline & & Jlh & $\%$ & Jlh & $\%$ & \\
\hline 1 & $\begin{array}{l}\text { Mahasiswa yang mampu mengerti } \\
\text { tentang materi yang dibahas }\end{array}$ & 10 & 25 & 15 & 37,5 & 12,5 \\
\hline 2 & $\begin{array}{l}\text { Mahasiswa yang mampu } \\
\text { menjelaskan materi }\end{array}$ & 11 & 27,5 & 20 & 5,0 & 39 \\
\hline 3 & $\begin{array}{l}\text { Mahasiswa yang mampu memberi } \\
\text { contoh }\end{array}$ & 10 & 25,0 & 17 & 42,5 & 17,5 \\
\hline 4 & $\begin{array}{l}\text { Mahasiswa yang mampu bertanya } \\
\text { dan kerja sama }\end{array}$ & 9 & 22,5 & 13 & 32,5 & 10 \\
\hline 5 & $\begin{array}{l}\text { Mahasiswa yang mampu } \\
\text { menyampaikan gagasan }\end{array}$ & 10 & 25,0 & 18 & 45 & 20 \\
\hline 6 & $\begin{array}{l}\text { Mahasiswa yang mampu memberi } \\
\text { tanggapan }\end{array}$ & 9 & 22,5 & 15 & 37,5 & 15 \\
\hline 7 & $\begin{array}{l}\text { Mahasiswa yang mampu } \\
\text { menyimpulkan tentang materi } \\
\text { yang dibahas }\end{array}$ & 8 & 20 & 14 & 35 & 25 \\
\hline
\end{tabular}

Dari Tabel 2 diatas terlihat bahwa pada siklus I ini terdapat dua pertemuan, dimana dua pertemuan tersebut mengalami peningkatan namun belum mencapai secara klasikal yaitu $85 \%$ mahasiswa aktif dalam belajar.

Dari persentase descriptor aktivitas siswa pada umumnya belum terlaksana secara sempurna, walaupun sudah ada peningkatan dilihat dari segi jumlah siswa yang aktivitas belajarnya dari pertemuan pertama, dan kedua dengan criteria baik. 
Tabel: 3 Tingkat Perubahan Aktivitas mahasiswa Pada Siklus 2

\begin{tabular}{|c|c|c|c|c|c|c|}
\hline \multirow[t]{2}{*}{ No } & \multirow[t]{2}{*}{ Aktivitas Belajar PHB } & \multicolumn{2}{|c|}{ Pertemuan 3} & \multicolumn{2}{|c|}{ Pertemuan 4} & \multirow{2}{*}{$\begin{array}{c}\text { Tingkat Perubahan } \\
\%\end{array}$} \\
\hline & & Jlh & $\%$ & Jlh & $\%$ & \\
\hline 1 & $\begin{array}{l}\text { Mahasiswa yang mampu mengerti } \\
\text { tentang materi yang dibahas }\end{array}$ & 25 & 62,5 & 35 & 87,5 & 25 \\
\hline 2 & $\begin{array}{l}\text { Mahasiswa yang mampu } \\
\text { menjelaskan materi }\end{array}$ & 26 & 65 & 33 & 82,5 & 17,7 \\
\hline 3 & $\begin{array}{l}\text { Mahasiswa yang mampu memberi } \\
\text { contoh }\end{array}$ & 30 & 75 & 35 & 87,5 & 12,5 \\
\hline 4 & $\begin{array}{l}\text { Mahasiswa yang mampu bertanya } \\
\text { dan kerja sama }\end{array}$ & 30 & 75.0 & 36 & 90,0 & 15,0 \\
\hline 5 & $\begin{array}{l}\text { Mahasiswa yang mampu } \\
\text { menyampaikan gagasan }\end{array}$ & 30 & 75,0 & 36 & 90,0 & 15,0 \\
\hline 6 & $\begin{array}{l}\text { Mahasiswa yang mampu memberi } \\
\text { tanggapan }\end{array}$ & 29 & 72,5 & 35 & 87,5 & 15,0 \\
\hline 7 & $\begin{array}{l}\text { Siswa yang mampu } \\
\text { menyimpulkan tentang materi } \\
\text { yang dibahas }\end{array}$ & 28 & 70,0 & 34 & 85,0 & 15,0 \\
\hline
\end{tabular}

Dari Tabel 3 terlihat bahwa dari pertemuan tiga sampai empat pada siklus kedua ini aktivitas belajar siswa sudah menunjukan peningkatan bila ditinjau dari ketuntasan aktivitas siswa secara klasikal, demikian pula dengan rata-rata kelas yang cenderung meningkat. Hal ini dapat dilihat dari nilai yang diperoleh mahasiswa setiap kelompok pertemuan.

Tabel: 4 Rata-rata Aktivitas mahasiswa Pada Siklus 1 dan siklus 2

\begin{tabular}{|c|c|c|c|c|c|c|}
\hline \multirow[t]{2}{*}{ No } & \multirow[t]{2}{*}{ Aktivitas Belajar PHB } & \multicolumn{2}{|c|}{ Rata-Rata Siklus 1} & \multicolumn{2}{|c|}{ Rata-rata Siklus 2} & \multirow{2}{*}{$\begin{array}{c}\text { Tingkat Perubahan } \\
\\
\%\end{array}$} \\
\hline & & Jlh & $\%$ & Jlh & $\%$ & \\
\hline 1 & $\begin{array}{l}\text { Mahasiswa yang mampu mengerti } \\
\text { tentang materi yang dibahas }\end{array}$ & 12,5 & 31,25 & 30 & 75 & 43,75 \\
\hline 2 & $\begin{array}{l}\text { Mahasiswa yang mampu } \\
\text { menjelaskan materi }\end{array}$ & 15,5 & 38,75 & 29,5 & 73,75 & 17,7 \\
\hline 3 & $\begin{array}{l}\text { Mahasiswa yang mampu memberi } \\
\text { contoh }\end{array}$ & 30 & 75 & 35 & 87,5 & 12,5 \\
\hline 4 & $\begin{array}{l}\text { Mahasiswa yang mampu bertanya } \\
\text { dan kerja sama }\end{array}$ & 30 & 75.0 & 36 & 90,0 & 15,0 \\
\hline 5 & $\begin{array}{l}\text { Mahasiswa yang mampu } \\
\text { menyampaikan gagasan }\end{array}$ & 30 & 75,0 & 36 & 90,0 & 15,0 \\
\hline 6 & $\begin{array}{l}\text { Mahasiswa yang mampu memberi } \\
\text { tanggapan }\end{array}$ & 29 & 72,5 & 35 & 87,5 & 15,0 \\
\hline 7 & $\begin{array}{l}\text { Mahasiswa yang mampu } \\
\text { menyimpulkan tentang materi } \\
\text { yang dibahas }\end{array}$ & 28 & 70,0 & 34 & 85,0 & 15,0 \\
\hline
\end{tabular}

Dari Tabel 4 diatas dapat dilihat bahwa dari dua siklus yang dilakukan terjadi peningkatan dari pertemuan satu sampai pertemuan empat dengan tujuh deskriptor yang ada.

\section{B. Pembahasan}


Berdasarkan analisis data penelitian yang dilakukan Pada program studi Pendidikan Ekonomi pada mata kuliah Penilaian Hasil Belajar Ekonomi pada sesi $\mathrm{B}$, menunjukan bahwa penggunaan pembelajaran kooperatif model dapat Aktif Tipe Bowling Campus meningkatkan aktifitas mahasiswa. Hal ini dapat dilihat dari meningkatnya keaktifan siswa dalam melakukan semua aktifitas pembelajaran. Hal ini dapat dilihat dari meningkatnya keaktifan mahasiswa dalam melakukan semua aktifitas belajar pada setiap siklus.

Dimana pada siklus I masing-masing aktifitas terjadi peningkatan dari tujuh indicator yang ada yaitu kemampuan dalam mengerti tentang materi $37,5 \%$, kemampuan mengamati, kemampuan menjelaskan50,0\%, kemampuan memberikan contoh $42,5 \%$, kemampuan bertanya dan bekerja sama $32,5 \%$,kemampuan menyampaikan gagasan $45 \%$, memberikan tanggapan 37,5\%, kemampuan menyimpulkan 35,0\%.

Pada siklus II masing-masing aktifitas yang ingin dicapai terjadi peningkatan dari tujuh indikator yang ada yaitu kemampuan mengerti mengalami peningkatan 87,5 \%, kemampuan menjelaskan mengalami kenaikan 82,5\%, kemampuan memberikan contoh mengalami kenaikan sebesar 87,5, kemampuan bertanya dan bekerja sama mengalami kenaikan sebesar 90,0 \%, kemampuan menyampaikan gagasan mengalami kenaikan sebesar 90,0\%, memberikan tanggapan mengalami kenaikan sebesar 87,5\%, kemampuan menyimpulkan mengalami kenaikansebesar $85,0 \%$.

\section{PENUTUP}

Berdasarkan data dan pembahasan dapat diambil kesimpulan bahwa penerapan pembelajaran kooperatif model dapat Aktif Tipe Bowling Campus yang dilakukan pada siklus I dan siklus II dapat meningkatkan aktivitas mahasiswa khususnya mata kuliah peneilaian hasil belajar ekonomi. Hal tersebut dapat dilihat dari perubahanperubahan aktifitas mahasiswa pada setiap pertemuan ada peningkatan pada masingmasing siklus.

Dari hasil penelitian yang dilakukan sebaiknya dosen harus teliti mendengarkan presentasi dari kelompok penyaji dan untuk meningkatkan aktifitas belajar mahasiswa dalam belajar maka dosen sebaiknya menggunakan model pembelajaran kooperatif Aktif Tipe Bowling Campus sehingga dapat meningkatkan aktivitas belajar mahasiswa.

\section{DAFTAR PUSTAKA}

10.22202/economica.2015.v4.i1.639

Arikunto, Suharsimi. 2006. Prosedur Penelitian. Jakarta: Rineka Cipta

Aunurrahman. 2009. Belajar dan

Pembelajaran. Bandung: Alfabeta

Dahar, Ratna Wilis. 2006. Teori-teori

Belajar dan Pembelajaran. Bandung: PT.

Gelora Aksara Pratama.

Dimyati dan Mudjiono. 2002. Belajar dan

Pembelajaran. Jakarta: Rineka Cipta

Hamalik, Oemar. 2011. Pendekatan Baru Strategi Belajar Mengajar Berdasarkan CBSA. Bandung: Sinar Baru Algensindo .2011. Proses Belajar Mengajar. Jakarta: Bumi Aksara

Mulyasa, E. 2010. Implementasi Kurikulum Tingkat Satuan Pendidikan Kemandirian Guru Dan Kepala Sekolah. Jakarta: Bumi Aksara

Sabri, Ahmad. 2007. Strategi Belajar Mengajar dan Micro Teaching. Jakarta: Quantum Teaching

Sanjaya, Wina. 2006. Strategi Pembelajaran Berorientasi Standar Proses Pendidikan. Jakarta: Kencana.

Silberman, Melvin L. 2006. Active Lerning: 101 Cara Belajar Siswa Aktif. Bandung: Nusamedia 
Slameto. 2003. Belajar dan Faktor-Faktor yang Mempengaruhi. Jakarta: Rineka Cipta

Sudjana, Nana. 2004. Penilaian Hasil Proses Belajar Mengajar. Bandung: Remaja Rosdakarya

Tim Pengembang MKDP. 2011. Kurikulum dan Pembelajaran. Jakarta: PT. Raja Grafindo Persada.

Uno, Hamzah. 2008. Model Pembelajaran. Jakarta: Bumi Aksara 